\title{
In vitro techniques for the evaluation of ruminant feeds
}

\section{By D. F. Osbourn and R. A. Terry, The Grassland Research Institute, Hurley, Maidenhead, Berkshire SL6 ${ }_{5} L R$}

For the purposes of this symposium in vitro techniques for the evaluation of ruminant feeds are defined as laboratory methods in which the availability of nutrients in the feed to the digestive process in the ruminant animal is estimated by the incubation of the feed with micro-organisms or semi-purified enzyme preparations, or both. Ewart (1974) reviewed for the Society recent developments in continuous in vitro rumen systems which are characterized by the continuous or intermittent removal of the products of fermentation and the feed residues. In batch in vitro systems, in contrast, there is no attempt to remove the feed residues and non-gaseous products of fermentation. In this review only batch in vitro methods will be examined as laboratory procedures for the estimation of the digestible (DE) or metabolizable (ME) energy contents of feeds and the metabolizable protein made available by diets.

\section{Some preliminary considerations}

Calibration of laboratory methods. In common with chemical procedures in vitro techniques are generally calibrated against estimates of digestibility made in vivo. The digestion of energy (Armstrong, 1964) and the degradability of dietary protein in the rumen (Miller, 1973) are both reduced by increasing the level of feeding and furthermore the effect of level of feeding appears to interact with the intrinsic degradability of each fraction. In order to comply with the ME system (ARC, I965) laboratory procedures should be calibrated against estimates of digestibility in vivo made at maintenance level of feeding, while it has been suggested (Miller, r973) that the extent of protein degradation should be made under conditions as close to ad lib. as possible.

Cell contents and cell walls. Extraction of feeds with a neutral detergent solution (Van Soest \& Wine, 1967) partitions the feed into two parts which behave nutritionally in very different ways. The cell contents are essentially 100\% available and only appear less available because of the metabolic faecal output of cell contents amounting to $12.9 \mathrm{~g}$ cell contents/100 $\mathrm{g}$ dry matter (DM) consumed (Van Soest \& Moore, 1965 ). The cell wall fraction is not completely digested and is non uniform in its behaviour (Lucas, I964), although the digestibility of both its major digestible constituents are highly correlated with the degree of lignification (Van Soest, 1967).

It follows from this, firstly, that the major difficulty in estimating the digestibility of feeds is the estimation of the availability of the cell wall fraction 
and, secondly, that estimates of cell wall availability alone cannot be expected to predict DM or organic matter (OM) digestibility, which are the summation of the apparently digested cell contents and the truly digested cell walls (Osbourn, Cammell, Terry \& Outen, 1975). This variation in the proportion of the apparently digested organic matter arising from cell walls severely limits the usefulness of chemical determinations such as acid detergent fibre and lignin or single stage in vitro procedures as methods for predicting digestibility. A second stage using a solvent or enzyme to solubilize protein is invariably required in addition to an estimate of cell wall degradation.

Partition of the cell wall fraction. The lack of nutritional uniformity in the cell wall fraction has led to attempts to isolate nutritionally uniform fractions within this complex using in vitro rate of digestion studies as the exploratory tool (Smith, Goering \& Gordon, 1972; Dekker, Richards \& Playne, 1972; Mertens, 1973). Wilkins (r 969) observed that two fractions were revealed as the result of prolonged digestion in vitro: a potentially digestible cellulose and a potentially indigestible cellulose. Waldo ( 1969 ) found that the behaviour of the potentially digestible cell wall fraction deviated from first order kinetics. Abe \& Horii (1974) using very high concentrations of cellulase to digest isolated grass cell walls have demonstrated two fractions in the cell walls each following first order kinetics. One fraction they suggest contains no lignin or crystalline polysaccharides and digests at 3.5 times the rate of the other fraction which contains the lignin and crystalline polysaccharides. Van Soest (1975) and Minson (1976) have both suggested that the failure to isolate nutritionally uniform fractions within the cell wall fraction make attempts to relate fibre determinations to digestibility in vivo while practical, ultimately unrewarding.

Minson (1976) has proposed that potential digestion as determined in vitro should be used as the basis of a model to describe the deviations observed in practice from this. A chemical method to partition the two fractions postulated by Abe \& Horii (1974) would be the ideal solution.

In vitro procedures and the estimation of digestible energy in feeds

Rumen liquor-pepsin method. Amongst the essential two-stage procedures, the most widely used is that proposed by Tilley, Deriaz \& Terry (1960) and described in detail by Tilley $\&$ Terry (1963). The method is based upon the incubation of the test substrate with rumen liquor followed by pepsin. Various modifications of this basic procedure have been proposed with the objectives of simplifying the equipment required (Alexander \& McGowan, 1961; Dent, 1963; Rogers \& Whitmore, 1966) and streamlining the procedure for the routine examination of large numbers of samples (Alexander \& McGowan, I966; Alexander, 1969; Minson \& McLeod, 1972).

The method was originally calibrated against in vivo determinations made on 148 frozen grasses and legumes given to mature wether sheep at restricted levels of feeding (Tilley \& Terry, r963) when the following relationship was obtained:

$$
\text { DMD viv }=0.99 \text { DMD vit }-1 \cdot 01 \quad R S D \pm 2 \cdot 31
$$


More recently the method was calibrated against 46 grasses and legumes using mature sheep fed at a maintenance level (Terry, Osbourn, Cammell \& Fenlon, 1973) with the following results ( $\mathrm{D}=\mathrm{g} \mathrm{DOM} / \mathrm{ro0} \mathrm{g} \mathrm{DM})$ :

$\begin{array}{rrr}\text { DMD viv }=1.01 & \text { DMD vit }+0.27 & \text { RSD } \pm 1.47 \\ \text { OMD viv }=1.02 & \text { OMD vit }+2.55 & \text { RSD } \pm 1.90 \\ D \text { viv }=0.98 & \text { D vit }+5.14 & \text { RSD } \pm 1.68\end{array}$

In the same study it was shown that the energy value of the organic matter digested was linearly related to crude protein $(\mathrm{N} \times 6.25)$ and that in consequence the digested energy (DE, MJ/kg DM) was most accurately predicted from a multiple regression relating $\mathrm{DE}$ to $\mathrm{D}$ vit and the crude protein content (CP) of the herbage.

$\mathrm{DE}=0.123 \mathrm{CP}+0.170 \mathrm{D}$ vit $+0.285 \mathrm{RSD} \pm 0.334$

Attempts to determine the energy value of the oM solubilized in vitro as the difference between the substrate and the residue have not been successful (Clark, 1958; Troelson, 1970). In addition to the technical difficulties of this approach, it is unlikely to succeed because the chemical composition of the residue from in vitro digestion and the animal faeces are markedly different not least in their ash content (McLeod \& Minson, 1974).

The standard error of duplicate samples examined with one rumen liquor was $\pm 0.66 \mathrm{DM}$ digestibility units and of duplicates between different batches of rumen liquor \pm I. I 8 (Tilley \& Terry, 1963). McLeod \& Minson (1974) have shown that the residual standard deviation of the regression of in vivo on in vitro is the best measure of the error of prediction for comparing laboratory methods.

Almost every aspect of the method has been investigated in an extensive literature (Minson \& McLeod, 1972). The major problem in the routine use of the method has been maintaining a uniform cellulolytic activity in the rumen liquor. Systematic variations arise from feeding the donor animals diets deficient in $\mathrm{N}$ (Minson \& McLeod, 1972) or high in starch (Terry, Tilley \& Outen, 1969). To overcome random week to week variation most laboratories include standard samples of known digestibility in each run and use their deviation from a long term average to correct all values for unknowns. In our laboratories examining fresh temperate grasses and legumes, we have found only very small improvements of no biological significance are available if separate species regressions are used instead of a pooled all species regression equation (Terry et al., 1973). However, in climatically more extreme environments (Troelson \& Bell, 1968; McLeod \& Minson, 1969) and in the examination of fresh grass, hays, silages and dried forages (van der Koelen \& Dijkstra, 197I) significant improvements have been found to result from separate regressions for species or forms of conservation, and hence standards appropriate to the forages being examined are used.

Despite these problems the two stage rumen liquor-pepsin in vitro technique has been found in practice to be the most precise method for estimating the digestibility of forages (Oh, Baumgardt \& Scholl, 1966; Cottyn, Hee \& van Carlier, 1971; van der Koelen \& Dijkstra, 1971; Newman, 1972; Reid, Post, Olson \& Mugerwa, 1973; and Tinnimit \& Thomas, 1976). The method has 
been widely used to evaluate varieties of grasses, legumes and brassicae (Dent, 1963) and in the selection of improved grass varieties (Cooper, Tilley, Raymond \& Terry, 1962; Burton, Hart \& Lowney, 1967).

Common misuses of the technique. McLeod \& Minson (1976) have shown that replication of the in vitro estimates cannot improve the error of predicting in vivo values which is determined by the RSD of the in vivo-in vitro regression. It has often been assumed that in vitro values are numerically equal to in vivo values and may be substituted one for another. This may be true if the in vivo values of standards are used for corrections, but in general the $Y=X$ situation is only approximately true for estimates of DM digestibility. Estimates of in vivo OMD and D-value should be calculated from the appropriate regression equations. Finally, the method has often been used to estimate the digestibility of feed samples in vivo where levels of feeding or the physical processing of the forage have caused increased rates of passage and depressions in the digestion in vivo. Thus the method cannot be used alone to estimate the digestibility in vivo of processed forages (Osbourn, Terry, Outen \& Cammell, 1976), nor can it be used with any accuracy to predict the actual digestibility if this is depressed by level of feeding. This is particularly true when attempts are made to estimate the intake of grazing animals on the basis of the indigestibility of samples of herbage ingested.

Alternative two stage in vitro procedures. Alternative procedures have substituted either chemical extractions for pepsin or the use of fungal cellulases for rumen liquor. Van Soest, Wine \& Moore ( 1967 ) followed incubation with rumen liquor by extraction with a neutral detergent solution. This shortened the time required and correlated very highly with in vivo estimates of true digestibility. Hartley, Jones \& Fenlon (1974) isolated plant cell walls and incubated them with a cellulase preparation and related cell wall digestibility to both the weight of cell walls digested and (for grasses only) to the ultra violet absorption induced by the carbohydrate esters of phenolic acids in the supernatant solution. The latter approach provides a very rapid method for the examination of large numbers of grass selections if further work confirms the validity of the relationship. Jones \& Hayward (1973, 1975) have used incubations with pepsin followed by cellulase to reduce dependence upon rumen liquor and to shorten the method. In our examination of this method we found it as accurate as the standard two stage method on grasses but less accurate on legumes (Table 1 ).

Cellulase preparations in their current forms digest much less of the cell walls of grasses than does the mixed microbial inoculation of rumen liquor used in vitro. Their specificity seems to make them less effective in the solubilization of the cell walls of legumes.

\section{In vitro procedures and the estimation of the metabolizable protein in diets}

Miller (1973) proposed a scheme for the evaluation of the contribution of a feedstuff to the microbial and dietary protein absorbed from diet in the small intestine of ruminants. In this scheme microbial protein synthesis, given adequate fermentable $\mathrm{N}$, would be estimated as $\mathrm{I} .68 \mathrm{~g} \mathrm{~N}=1.03 \mathrm{~g}$ absorbed amino acid $\mathrm{N} / \mathrm{MJ}$ 
Table I. The residual standard deviation of regressions of dry matter digestibility determined in vivo on dry matter digestibility determined in vitro by alternative troo stage in vitro procedures

\begin{tabular}{|c|c|c|c|c|}
\hline \multirow[b]{2}{*}{ Method } & \multicolumn{3}{|c|}{ Sample grouping } & \multirow[b]{2}{*}{ Reference } \\
\hline & Grasses & Legumes & $\begin{array}{c}\text { Grasses and } \\
\text { legumes }\end{array}$ & \\
\hline $\begin{array}{l}\text { Rumen liquor-pepsin } \\
\text { Rumen liquor-detergent } \\
\text { Pepsin-Cellulase } \\
\text { Pepsin-Cellulase } \\
\text { Detergent-cellulase }\end{array}$ & $\begin{array}{l}1 \cdot 46\left(4^{8}\right)^{\circ} \\
2.88(19) \\
1 \cdot 80\left(4^{8)}\right.\end{array}$ & $\begin{array}{c}1 \cdot 91(25) \\
\bar{Z} \\
3 \cdot 17(25)\end{array}$ & $\begin{array}{c}1 \cdot 60(73) \\
2 \cdot 80(20) \\
3 \cdot 80(73)\end{array}$ & $\begin{array}{l}\text { Terry et al. (1977) } \\
\text { Van Soest et al. (1967) } \\
\text { Jones \& Hayward (1975) } \\
\text { Terry et al. (1977) }\end{array}$ \\
\hline $\begin{array}{l}\text { Optical density } \\
\text { Cell wall residue }\end{array}$ & $\begin{array}{l}\text { I. } 42(27) \\
\text { I.55(27) }\end{array}$ & - & - & $\begin{array}{l}\text { Hartley et al. (1974) } \\
\text { Hartley et al. (1974) }\end{array}$ \\
\hline
\end{tabular}

-Value in parenthesis are the number of samples examined.

metabolizable energy consumed, and was based on the assumptions that $27 \mathrm{~g}$ microbial $\mathrm{N}$ would be synthesized per $\mathrm{kg}$ OM fermented in the rumen and that $70 \%$ of the apparently digested oM would be digested in the rumen. If these assumptions were true, then in vitro estimates of the DOM in feeds would be of major value in predicting microbial protein synthesized. The two assumptions are interdependent and have been questioned. The yield of microbial protein per $\mathrm{kg}$ oM fermented increases with increasing dilution rate (Hobson \& Summers, 1967; Harrison, Beever, Thomson \& Osbourn, 1975) and decreases when uncoupled fermentation occurs (Hume, Moir \& Somers, 1970; Beever, Thomson, Cammell \& Harrison, 1977) although this appears to be associated with a deficiency of fermentable $\mathrm{N}$ or sulphur (Armstrong, 1976).

The proportion of the apparently digested om fermented in the rumen is variable also. McMeniman (1975) observed that for seventeen hay-concentrate diets fed to cattle the mean value was $0.976 \pm 0.024$. On diets reported by Beever, Thomson \& Harrison (1974) values varying from $67-93 \%$ were recorded. Dietary starch (McAllan \& Smith, 1976) and the water soluble carbohydrates of forages are entirely fermented in the rumen, while $90 \%$ of the digestible cellulose and $70-80 \%$ of the digested hemicellulose are fermented in the rumen on long forage diets. Thus it may be necessary to determine the separate carbohydrate fractions and their retention time in the rumen to accurately estimate the om fermented in the rumen.

Hendrickx \& Martin ( 1967 ) used the release of ammonia in vitro as a measure of proteolysis and related this to the solubility of proteins in rumen liquor.

Under specific conditions correlations have been demonstrated between measures of protein solubility and the total flow of $\mathrm{N}$ into the small intestine (Beever, Thomson \& Cammell, 1976) and $\mathrm{N}$ retention (Preston, Whitelaw \& McLeod, 1963). However, in our own studies the proportion of dietary protein degraded in the rumen was poorly correlated with simple enzymic or chemical tests of solubility (R. C. Siddons, unpublished results).

The technical difficulty of separating the undigested dietary protein from microbial protein using in vitro methods and known effects of level of feeding on 
the degradation of dietary protein make it doubtful if a simple batch in vitro procedure used in conjunction with a marker can be used to solve this problem.

\section{Conclusions}

In vitro methods occupy an uneasy position between the generally fallible chemical methods and direct animal estimates of the nutritive value of feeds for ruminants. Despite the lower errors of prediction of in vivo digestion in vitro methods are generally too slow and costly for routine commercial evaluations. The use of cellulase preparations seems likely to replace rumen liquor in research and grass selection programmes, but would be increased if less specific preparations could be found.

The future development of in vitro methods seems likely to be towards the investigation of the intrinsic variations in the rate of digestion or potential digestibility of the cell wall and protein fraction of feeds unless physico chemical methods of analysis can provide the basis for isolating nutritionally uniform fractions within these two constituents of feeds.

\section{REFERENCES}

Abe, A. \& Horii, S. (1974). F. Fapan. Grassl. Sci. 1, I6.

Agricultural Research Council $(1965)$. The nutrient requirements of farm livestock No. 2 Ruminants. Agricultural Research Council, London HMSO.

Alexander, R. H. (1969). Res. Bull. W. Scotl. Coll. Agric. No. 42.

Alexander, R. H. \& MeGowan, M. (1961). F. Br. Grassld Soc. 16, 175.

Alexander, R. H. \& McGowan, M. (1966). F. Br. Grassld Soc. $21,140$.

Armstrong, D. G. (1964). F. agric. Sci., Camb. 62, 399.

Armstrong, D. G. (1976). Ubers. Tierernahrg. 4, 1.

Beever, D. E., Thomson, D. J. \& Cammell, S. B. (1976). F. agric. Sci., Camb. 86, 443.

Beever, D. E., Thomson, D. J., Cammell, S. B. \& Harrison, D. G. (1977). J. agric. Sci, Camb. 88, 61 .

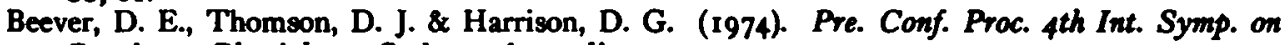
Ruminant Physiology, Sydney, Australia p. 123.

Burton, G. E., Hart, R. H. \& Lowney, R. S. (1967). Crop. Sci. 7, 329.

Clark, K. W. (1958). Diss. Abstr. 19, (5), 926.

Cooper, J. P., Tilley, J. M. A., Raymond, W. F. \& Terry, R. A. (1962). Nature, Lond. 195, 1276.

Cottyn, B. E., Hee, L. P. \& Van Carlier, L. A. (1971). Reoue Agric. Brux. 23, 1491.

Dekker, R. F. H., Richards, G. N. \& Playne, J. M. (1972). Carbohydrate Res. 22, 173.

Dent, J. W. (1963). F. Br. Grassld Soc. 18, 181.

Ewart, J. M. (1974). Proc. Nutr. Soc. 33, 125.

Goering, H. K. \& Van Soest, P. J. (1970). Forage fibre analysis Handbook No. 379. Washington, DC: Agriculture Research Service.

Harrison, D. G., Beever, D. E., Thomson, D. J. \& Osbourn, D. F. (1975). F. agric. Sci., Camb. $85,93$.

Hartley, R. D., Jones, E. C. \& Fenlon, J. S. (1974). F. Sci. Fd Agric. 25, 947.

Hendrickx, H. \& Martin, J. (1967). C. R. Rech. Inst. Encour. Rech. Scient. Ind. Agric. 31, 9.

Hobson, P. N. \& Summers, N. (1967). F. gen. Microbiol. 47, 53.

Hume, I. D., Moir, R. J. \& Somers, M. (1970). Aust. F. agric. Res. 21, 283.

Jones, D. I. H. \& Hayward, M. V. (1973). F. Sci. Fd Agric. $24,1419$.

Jones, D. I. H. \& Hayward, M. V. (1975). F. Sci. Fd Agric. 26, 711 .

Lucas, H. L. $(1964)$. In Stochostic Models in Medicine and Biology. [J. Gurland, editor]. Madison: University of Wisconsin Press.

McAllan, A. B. \& Smith, R. H. (1976). Br. F. Nutr. 36, 511.

McLeod, M. N. \& Minson, D. J. (1969). F. Br. Grassld Soc. 24, 244.

McLeod, M. N. \& Minson, D. J. (1974). J. Br. Grassld Soc. 29, 17.

McLeod, M. N. \& Minson, D. J. (1976). Anim. Fd Sci. Technol. 1, 61. 
McMeniman, N. P. (1975). Aspects of nitrogen metabolism in the rumirant PhD thesis. Dept. agric. Biochem., Univ. Newcastle upon Tyne.

Mertens, D. R. (1973). Application of theoretical mathematical models to cell wall digestion and forage intake in ruminants $\mathrm{PhD}$ thesis. Cornell University.

Miller, E. L. (1973). Proc. Nutr. Soc. 32, 79.

Minson, D. J. (1976). Misc. Papers 12 Landbourwholgeschool Wageningen, Netherlands.

Minson, D. J. \& McLeod, M. N. (1972). Technical paper, Division of Tropical Pastures CSIRO Australia No. 8 I 5 pp (En).

Minson, D. J. Milford, R. (1966). Aust. J. agric. Res. 17, 411.

Newman, D. M. R. (1972). f. Aust. Inst. agric. Sci. 38, 212.

Oh, Hi, Kon., Baumgardt, B. R. \& Scholl, J. M. (I966). F. Dairy Sci. 49, 850.

Osbourn, D. F., Cammell, S. B., Terry, R. A. \& Outen, G. E. (1975). F. Br. Grassld. Soc. 30, 101.

Osbourn, D. E., Terry, R. A., Outen, G. E. \& Cammell, S. B. (1976). Proc. XIIth Int. Grassld Congr. Mosconv, 1974, 3, 374.

Preston, T. R., Whitelaw, F. G. \& Mcleod, N. A. (1963). Anim. Prod. 5, 147.

Reid, R. L. A., Post, A. J., Olsen, F. J. \& Mugerw2, J. S. (1973). Trop. Agric. Trin. 50, I.

Rogers, H. H. \& Whitmore, E. T. (1966). J. Br. Grassld. Soc. 21 , I54.

Smith, L. W., Goering, H. K. \& Gordon, C. H. (1972). F. Dairy Sci. 55, 1140.

Terry, R. A., Mundell, D. C. \& Osbourn, D. F. (1977). F. Br. Grassld. Soc. (In the Press).

Terry, R. A., Osbourn, D. F., Cammell, S. B. \& Fenlon, J. S. (1973). Proc. 5th Gen. Mtg Euro. Grassld Fd. Uppsala 1973 Vaxtodling 28 ig.

Terry, R. A., Tilley, J. M. A. \& Outen, G. E. (1969). Y. Sci. Fd Agric. 20, 317.

Tilley, J. M. A., Deriaz, R. E. \& Terry, R. A. (1960). Proc. 8th int. Grassld Congr. Reading 533.

Tilley, J. M. A. \& Terry, R. A. (1963). F. Br. Grassld Soc. 18, 104.

Tinnimit, P. \& Thomas, J. W. (1976). f. anim. Sci. 43, 1058.

Troelsen, J. E. (1970). Can. F. Anim. Sci. 50, 557.

Troelsen, J. E. \& Bell, J. M. (1968). Can. f. Anim. Sci. 48, 361.

van der Koelen, C. J. \& Dijkstra, N. D. (1971). Landbourokundig. Tijdschrift 83 (12), 484.

Van Soest, P. J. (1967). f. Anim Sci. 26, I19.

Van Soest, P. J. (1975). In Digestion and Metabolism in the Ruminant. pp. 351-65. [I. W. McDonald and A. C. I. Warner, editors].

Van Soest, P. J. \& Moore, L. A. (1965). Proc. 9th Int. Grassld Congr. Sao Paulo, Bravil 783.

Van Soest, P. J. \& Wine, R. H. (1967). 7. Ass. off. Analyt. Chem. 50, 50.

Van Soest, P. J., Wine, R. H. \& Moore, L. A. (1967). Proc. roth Int. Grassld. Congr. Helsinki $1966,43^{8}$.

Waldo, D. R. (1969). Proc. Nat. Conf. Forage Quality and Utilisation (USA) EI-E22 USDA.

Wilkins, R. J. (1969). f. agric. Sci., Camb. 73, 57. 